\title{
Pollen morphology and viability in Bromeliaceae
}

\author{
EVERTON H. SOUZA ${ }^{1}$, FERNANDA V.D. SOUZA ${ }^{2}$, MÔNICA L. ROSSI ${ }^{1}$, RENAN M. \\ PACKER ${ }^{1}$, MARIA AMELIA V. CRUZ-BARROS ${ }^{3}$ and ADRIANA P. MARTINELLI ${ }^{1}$ \\ ${ }^{1}$ Universidade de São Paulo, Centro de Energia Nuclear na Agricultura, Av. Centenário, \\ 303, São Dimas, Caixa Postal 96, 13400-970 Piracicaba, SP, Brazil \\ ${ }^{2}$ Embrapa Mandioca e Fruticultura, Rua Embrapa, s/n, Chapadinha, 44380-000 Cruz das Almas, BA, Brazil \\ ${ }^{3}$ Instituto de Botânica, Secretaria do Meio Ambiente do Estado de São Paulo, Av. Miguel \\ Stéfano, 3687, Água Funda, Caixa Postal 4005, 04301-902 São Paulo, SP, Brazil
}

Manuscript received on June 9, 2017; accepted for publication on August 25, 2017

\begin{abstract}
Pollen morphology characterization is important in taxonomy, conservation and plant breeding, and pollen viability studies can support breeding programs. This study investigated pollen morphology and male fertility in 18 species of Bromeliaceae with ornamental potential. For morphological characterization, pollen grains were acetolyzed and characterization of exine was done using scanning and transmission electron microscopy. Pollen viability was investigated by in vitro germination and histochemical tests. Species belonging to Aechmea and Ananas genera presented medium size pollen, except for Ae. fasciata, with large pollen. Al. nahoumii, P. sagenarius and the Vriesea species analyzed showed large pollen, except for $V$. carinata, with very large pollen. Pollen of Aechmea, Ananas and P. sagenarius presented bilateral symmetry, diporate, exine varying from tectate to semitectate. Al. nahoumii and Vriesea species presented pollen with bilateral symmetry, monocolpate; exine was semitectate, reticulate and heterobrochate. Germination percentage and tube growth were greater in SM and BKM media. Histochemical tests showed pollen viability above $70 \%$ for all species, except for Ananas sp. (40\%). Pollen morphology is important for the identification of species, especially in this family, which contains a large number of species. High rates of viability favor fertilization and seed production, essential for efficient hybrid production and conservation.
\end{abstract}

Key words: Aechmea, Alcantarea, Ananas, in vitro pollen germination, histochemical test, Vriesea.

\section{INTRODUCTION}

The family Bromeliaceae belongs to the order Poales and contains around 58 genera and 3,904 species (Butcher and Gouda 2017), making it the largest family with natural distribution restricted to the New World, except for Pitcairnia feliciana

Correspondence to: Everton Hilo Souza

E-mail: hilosouza@gmail.com
(Aug. Chev.) Harms \& Mildbr, a native of Guinea in West Africa (Smith and Downs 1974, 1977, 1979, Givnish et al. 2007, 2011).

There are about 43 genera and 1,246 species in Brazil, 1,067 of them endemic, making the country the most biodiverse regarding the family, which is found in almost all the country's ecosystems. The Atlantic Forest has the largest diversity (Forzza et 
al. 2013). Due to their high ornamental potential, the bromeliads are vulnerable to intensive extractive activity. Therefore, many reproductive studies have been carried out to generate knowledge about the preservation and genetic improvement of these plants.

The Bromeliaceae were traditionally classified into three subfamilies: Bromelioideae, Tillandsioideae and Pitcairnioideae (Smith and Downs 1974, 1977, 1979). However, only the first two are monophyletic (Givnish et al. 2004, $2007,2011)$. Thus, relying on the phylogenetic and molecular hypotheses, Givnish et al. $(2007,2011)$ proposed a new division of the family, in which the different clades related to the former Pitcairnioideae are considered different subfamilies. Therefore, this family now presents eight subfamilies: Brocchinioideae, Bromelioideae, Hechtioideae, Lindmanioideae, Navioideae, Pitcairnioideae, Puyoideae and Tillandsioideae.

Pollen, as the structure responsible for transferring the male genetic material, is the focus of many studies involving a large number of species (Hesse et al. 2009). Studies of pollen morphology of the Bromeliaceae have provided data on taxonomy, helping to delineate genera and species that are very similar (Halbritter 1992, Barfuss et al. 2005).

Pollen morphological characteristics were used for the first time to study Bromeliaceae by Mez (1891-1894, 1896). However, considering this family's size, despite previous studies regarding pollen morphology, e.g., Ehler and Schill (1973), Erdtman and Praglowski (1974), Wanderley and Melhem (1991), Halbritter (1992), Halbritter and Till (1998), Tardivo and Rodrigues (1998), Vervaeke et al. (2003), Souza et al. (2004, 2015), Moreira et al. (2005) and Silva et al. (2016), demand to expand this knowledge to more species is significant. So far around 750 species have been studied, using different microscopic techniques to characterize the pollen, to contribute to the taxonomy, conservation and breeding of this family.
In addition to morphology, knowledge of the viability and longevity of pollen is crucial to preservation efforts and genetic improvement of many species (Souza et al. 2015). Conservation of pollen is also important to basic research, allergy testing, traceability studies and exchange and preservation of germplasm (Volk 2011).

To be useful for research, preserved pollen must be viable. Therefore, this needs to be monitored before, during and after storage, to establish the maximum period in which pollen can remain preserved without losing its properties and thus its ability to germinate (Souza et al. 2015).

Pollen viability can be determined by various techniques. These can be grouped into direct methods such as in vitro germination (Parton et al. 2002, Kumari et al. 2015, Souza et al. 2015) and in vivo germination (Souza et al. 2015), or indirect methods based on parameters such as cytological staining (Kearns and Inouye 1993, Kumari et al. 2015, Souza et al. 2015). Despite being simple, quick and inexpensive, histochemical tests do not provide information about the germination of pollen.

In vitro germination is the most widely used method to determine the fertility of pollen, by investigating the development of the pollen tube. The success of in vitro germination depends on several factors, such as species, nutritional status of plants, time and method of collecting pollen, photoperiod, temperature, incubation period and composition of the germination media (Taylor and Hepler 1997, Soares et al. 2015), which need to be adjusted for each species (Brewbaker and Kwach 1963, Dafni 1992). To obtain reliable estimates of pollen viability, it is necessary to define a germination medium that permits the expression of its physiological potential for the formation of the pollen tube. Different media for in vitro germination of pollen have been reported for a large number of species, with considerable intra- and interspecific variation (Parton et al. 2002). 
The in vitro germination of pollen of various species is performed in germination media containing carbohydrates and germination stimulants (micronutrients and hormones). Many organic and inorganic substances, such as sucrose, boric acid, calcium nitrate, potassium nitrate and magnesium sulfate, exert effects on the in vitro germination of pollen (Parton et al. 2002). Sucrose is intended to provide osmotic balance between the pollen and the germination medium and to provide energy to assist the development of the pollen tube (Stanley and Linkens 1974). Boron and calcium are essential for the germination and the growth of pollen tubes, minimizing the sensitivity to variations in the germination medium, affecting membrane permeability and stiffening the pollen tube (Bhojwani and Bhatnagar 1974).

Like pollen morphology studies, little has been published about the viability of pollen from Bromeliaceae. Wee and Rao (1979) evaluated the germination of pollen of two species of the genus Ananas in different concentrations of vitamins and hormones and obtained germination percentages below $33 \%$ and pollen tube length of less than 1.843 $\mu \mathrm{m}$. Parton et al. (2002) studied three different germination media for seven species of the genera Aechmea, Vriesea, Guzmania and Tillandsia and obtained germination percentages ranging from $0 \%$ in Guzmania 'Daniel' to $95 \%$ in Ae fasciata, in germination media containing only boric acid $(0.01 \%)$ and sucrose (20\%). Palma-Silva et al. (2004) evaluated the viability by histochemistry using Alexander's stain (1980) in ten Vriesea species and obtained viability higher than $90 \%$. Soares et al. (2011) studied different species of the genus Ananas using two incubation temperatures $\left(25^{\circ} \mathrm{C}\right.$ and $30^{\circ} \mathrm{C}$ ) for in vitro germination of pollen and observed that $25^{\circ} \mathrm{C}$ was the most suitable temperature for $P$. sagenarius, while for the other varieties there was no difference between the optimal temperatures.
To obtain information that can improve the family's taxonomy and conservation of species, and also to support genetic improvement programs, we studied the pollen morphology patterns and evaluated male fertility of species with ornamental potential of the Bromeliaceae family.

\section{MATERIALS AND METHODS}

\section{PLANT MATERIALS AND GROWTH CONDITIONS}

Plants of 18 species of Bromeliaceae with ornamental potential were cultivated in a greenhouse, in plastic pots $(13 \mathrm{~cm}$ height by $10 \mathrm{~cm}$ diameter), with Basaplant ${ }^{\circledR}$ substrate, at ambient temperature and relative humidity of $70 \%$, in the municipality of Piracicaba, São Paulo state, Brazil. A pilot study was carried out to determine the time to flower opening. The pollen grains were collected from flowers at anthesis.

One specimen of each was deposited in the ESA herbarium ("Luiz de Queiroz" School of Agriculture/ University of São Paulo - Esalq/USP): Aechmea bicolor L. B. Sm. (voucher ESA 120990), Ae. bromeliifolia Baker ex Benth. \& Hook. f. (ESA 121275), Ae. distichantha Lem. (ESA 121281), Ae. fasciata Baker (ESA 120987), Ae. nudicaulis Griseb. (ESA 120991), Ananas sp. (L.) Merr. (ESA 120988), An. ananassoides (Baker) L. B. Smith (ESA 121274), An. bracteatus (Lindley) Schultes f. (ESA 121284), An. lucidus Miller (ESA 121285), An. parguazensis Camargo \& L. B. Smith (ESA 121405), Alcantarea nahoumii (Leme) J. R. Grant (ESA 120986), Pseudananas sagenarius (Arruda da Camara) Camargo (ESA 121286), Vriesea carinata Wawra (ESA 121404), V. friburgensis Mez (ESA 121282), V. michaelii W. Weber (ESA 121280), V. paraibica Wawra (ESA 121276), $V$. simplex Beer (ESA 120989) and $V$. unilateralis Mez (ESA 121283). 


\section{POLLEN ULTRASTRUCTURE}

For morphological and ultrastructural characterization, the pollen were fixed in modified Karnovsky solution (Karnovsky 1965) [glutaraldehyde (2\%), paraformaldehyde (2\%), $\mathrm{CaCl} 2(0.001 \mathrm{M})$, sodium cacodylate buffer $(0.05 \mathrm{M})$ at $\mathrm{pH}$ 7.2] for 48 hours, and then dehydrated in an ethyl alcohol series (35-100\%), 20 min each. The samples were dried in HMDS (hexamethyldisilazane), mounted on metal stubs and sputter coated with gold for analysis under an LEO 435 scanning electron microscope (SEM) (Carl Zeiss, Jena, Germany), and digital images were recorded.

For transmission electron microscopy (TEM), the pollen grains were fixed in the same modified Karnovsky solution (Karnovsky 1965) for 24 hours. Subsequently, they were washed in sodium cacodylate buffer $(0.1 \mathrm{M})$ and immediately post-fixed in osmium tetroxide (1\%) for 1 hour, followed by washing in saline solution $(0.9 \%$ sodium chloride) and pre stained with uranyl acetate $(2.5 \%)$. Then the samples were dehydrated in an increasing acetone series (35-100\%) for 20 min each what that. The samples were then gradually infiltrated in Spurr resin and embedded in pure resin for 48 hours at $70{ }^{\circ} \mathrm{C}$. The blocks were sectioned with an ultramicrotome (Sorvall Porter Blum MT2, Norwalk, USA). The ultrathin sections $(60 \mathrm{~nm})$ obtained were deposited on copper grids previously covered with Formvar ${ }^{\circledR}$ and contrasted in uranyl acetate $(2.5 \%)$ and lead citrate according to Reynolds (1963). The images were obtained with a Zeiss EM900 transmission electron microscope (Carl Zeiss, Jena, Germany).

\section{PRODUCTION AND SIZE OF POLLEN}

The number of pollen grains was estimated counting the number of pollen grains produced per flower, considering six anthers per flower. Three flowers were collected from three different inflorescences and anthers were individually stored in Eppendorf tubes, following methodology described by Kearns and Inouye (1993). Acetolyzed pollen grains were used for measuring pollen grain size, following weak lactic acetolysis (ACLAC 40), as described by Raynal and Raynal (1979). Polar and equatorial diameters of 25 random pollen grains in equatorial view were measured by the ImageJ $1.46 \mathrm{r}$ software (Rasband 1997-2012). The pollen grains were classified according to the nomenclature described by Punt et al. (2007).

\section{In vitro POLLEN GERMINATION}

Pollen grains were inoculated in Petri dishes containing $35 \mathrm{ml}$ of four germination media, as described below: $\mathrm{BM}: \mathrm{H}_{3} \mathrm{BO}_{3}(0.01 \%)$; sucrose (20\%); agar (0.5\%); pH 6.5 (Parton et al. 2002); BKM: $\mathrm{H}_{3} \mathrm{BO}_{3}(0.01 \%)$; $\mathrm{Ca}\left(\mathrm{NO}_{3}\right)_{2} * 4 \mathrm{H}_{2} \mathrm{O}(0.03 \%)$; $\mathrm{MgSO}_{4 *} 7 \mathrm{H}_{2} \mathrm{O}(0.02 \%) ; \mathrm{KNO}_{3}(0.01 \%)$; sucrose (10\%); agar (0.5\%); pH 6.5 (Brewbaker and Kwack 1963); MBKM: $\mathrm{H}_{3} \mathrm{BO}_{3}(0.01 \%) ; \mathrm{Ca}\left(\mathrm{NO}_{3}\right)_{2} * 4 \mathrm{H}_{2} \mathrm{O}$ (0.03\%); $\mathrm{MgSO}_{4 *} 7 \mathrm{H}_{2} \mathrm{O}(0.02 \%) ; \mathrm{KNO}_{3}(0.01 \%)$; sucrose (20\%); agar (0.5\%); pH 6.5 (Brewbaker and Kwack 1963, modified); SM: $\mathrm{H}_{3} \mathrm{BO}_{3}(0.01 \%)$; $\mathrm{Ca}\left(\mathrm{NO}_{3}\right)_{2} * 4 \mathrm{H}_{2} \mathrm{O}(0.03 \%) ; \mathrm{MgSO}_{4} * 7 \mathrm{H}_{2} \mathrm{O}(0.02 \%)$; $\mathrm{KNO}_{3}(0.01 \%)$; sucrose (15\%); agar (0.8\%); pH 6.5 (Soares et al. 2008).

With the aid of a brush, the grains were distributed in the germination media in Petri dishes, which were maintained in an incubator at $27 \pm 1{ }^{\circ} \mathrm{C}$. The experimental design for pollen germination was completely randomized with four culture media in 12 replicates, each consisting of three Petri dishes, divided into four quadrants.

The germination rate and length of pollen tubes were measured 24 hours after inoculation in the germination media. Photomicrographs were obtained using a Leica EZ4 D stereomicroscope (Leica, Wetzlar, Germany).

The germination percentage was determined by counting all the pollen grains in each quadrant 
(at least 1,000 per treatment). Pollen tube length was established by randomly measuring five pollen tubes in each quadrant, or a total of 60 pollen tubes per treatment. Pollen grains were considered germinated when pollen tube length was greater than twice the pollen diameter.

The germination percentage data was transformed by $\operatorname{arc} \sin (\sqrt{ } \mathrm{x} / 100)$ prior to statistical analysis. For comparison of means, data was submitted to analysis of variance (ANOVA) followed by the Scott-Knott test $(\mathrm{p}<0.01)$, using the SAS program (SAS Institute 2004).

\section{HISTOCHEMICAL ANALYSIS OF POLLEN VIABILITY}

For pollen viability analysis, three stains were used: Alexander solution (222 mM lactic acid, Alexander 1980), acetocarmine (10 $\mathrm{g} \mathrm{L}^{-1}$, Kearns and Inouye
1993) and Sudan IV (26 mM, Baker and Baker 1979). Anthers collected from three flowers of three different plants were placed on a glass slide and the pollen grains were spread on the slide. One drop of a given staining solution was added per slide, and the samples were covered with a coverslip for observation under a light microscope. One hundred pollen grains were counted per slide, with three replications, each consisting of one slide. The percent of viable pollen was calculated as the average of three replicates.

The viability data were also transformed by $\operatorname{arc} \sin (\sqrt{ } \mathrm{x} / 100)$ prior to statistical analysis. For comparison of means, the data was submitted to analysis of variance (ANOVA) followed by the Scott-Knott test $(\mathrm{p}<0.01)$, using the SAS program (SAS Institute 2004).

TABLE I

Morphometric characteristics and estimate number of grains per Bromeliaceae flower of the genera Aechmea, Ananas, Alcantarea, Pseudananas, and Vriesea.

\begin{tabular}{|c|c|c|c|c|}
\hline \multirow[b]{2}{*}{ Species } & \multicolumn{2}{|c|}{ Equatorial view } & \multirow[b]{2}{*}{ Size } & \multirow{2}{*}{$\begin{array}{c}\text { Estimate number of } \\
\text { pollen grains }\end{array}$} \\
\hline & Polar diameter $(\mu \mathrm{m})$ & $\begin{array}{l}\text { Equatorial diameter } \\
(\mu \mathrm{m})\end{array}$ & & \\
\hline Aechmea bicolor & $21.95 \pm 1.56$ & $31.63 \pm 1.34$ & Medium & 32,916 \\
\hline Ae. bromeliifolia & $35.39 \pm 1.64$ & $44.09 \pm 2.06$ & Medium & 32,080 \\
\hline Ae. distichantha & $34.58 \pm 2.04$ & $47.16 \pm 2.15$ & Medium & 221,666 \\
\hline Ae. fasciata & $57.32 \pm 1.66$ & $79.34 \pm 3.83$ & Large & 119,167 \\
\hline Ae. nudicaulis & $32.97 \pm 2.87$ & $42.64 \pm 2.89$ & Medium & 59,167 \\
\hline Ananas sp. & $29.29 \pm 2.39$ & $36.10 \pm 2.11$ & Medium & 58,300 \\
\hline An. ananassoides & $31.28 \pm 2.58$ & $39.10 \pm 2.15$ & Medium & 61,083 \\
\hline An. bracteatus & $39.23 \pm 2.24$ & $47.80 \pm 3.41$ & Medium & 90,830 \\
\hline An. lucidus & $37.64 \pm 1.92$ & $44.70 \pm 3.03$ & Medium & 68,900 \\
\hline An. parguazensis & $36.24 \pm 2.37$ & $46.16 \pm 2.48$ & Medium & 63,167 \\
\hline Alcantarea nahoumii & $45.32 \pm 2.04$ & $67.78 \pm 4.19$ & Large & 112,333 \\
\hline Pseudananas sagenarius & $45.29 \pm 1.98$ & $51.12 \pm 2.13$ & Large & 71,128 \\
\hline Vriesea carinata & $44.42 \pm 2.78$ & $100.17 \pm 6.11$ & Very large & 115,416 \\
\hline$V$. friburgensis & $49.71 \pm 2.76$ & $87.77 \pm 4.31$ & Large & 112,083 \\
\hline V. michaelii & $39.39 \pm 2.68$ & $88.17 \pm 7.51$ & Large & 158,333 \\
\hline$V \cdot$ paraibica & $53.49 \pm 1.74$ & $89.90 \pm 3.98$ & Large & 118,833 \\
\hline V. simplex & $52.05 \pm 3.33$ & $74.13 \pm 3.34$ & Large & 126,666 \\
\hline V. unilateralis & $45.83 \pm 3.27$ & $66.31 \pm 4.43$ & Large & 114,550 \\
\hline
\end{tabular}




\section{RESULTS}

\section{POLLEN GRAIN MORPHOLOGY}

The pollen grain size was classified into medium for the species of the genera Aechmea and Ananas, except for Ae. fasciata, which together with $A l$. nahoumii, $P$. sagenarius and Vriesea presented pollen with large size. $V$. carinata was the only species with very large pollen (Table I).

In Aechmea, we observed approximately 30,000 grains per flower for Ae. bicolor and Ae. bromeliifolia, while Ae. distichantha presented on average 221,666 grains per flower. Among the species of the genus Vriesea the variation was less pronounced, with an estimate between 112,000 and 126,000 grains for $V$. carinata, $V$. friburgensis, $V$. paraibica, V. simplex and $V$. unilateralis, and about 158,000 grains for $V$. michaelii (Table I).

Observation of ultrathin sections of the sporoderm of pollen by transmission electron microscopy can reveal the exine layers externally and the intine layers internally. There was variation in the thickness of the exine layers according to the species studied, from $1.41 \pm 0.09 \mu \mathrm{m}$ for Ae. bicolor to $4.00 \pm 0.34 \mu \mathrm{m}$ for $V$. unilateralis (Table II).

\section{GENUS Aechmea}

Ae. bicolor: medium pollen, bilateral symmetry, oblate shape, diporate, with a more convex side and the other flatter, tectate exine, psilate (Figure 1a-d). Ae. bromeliifolia: medium pollen, bilateral symmetry, oblate shape, diporate, exine tectate,

TABLE II

Morphometric characteristics of exine layers of pollen grains of Bromeliaceae of the genera Aechmea, Ananas, Alcantarea, Pseudananas, and Vriesea.

\begin{tabular}{|c|c|c|c|c|c|}
\hline \multirow{2}{*}{ Species } & Tectum & Columellae & Sexine & Nexine & Exine \\
\hline & \multicolumn{5}{|c|}{$\mu \mathrm{m}$} \\
\hline Aechmea bicolor & $0.64 \pm 0.06$ & $0.23 \pm 0.03$ & $0.87 \pm 0.07$ & $0.54 \pm 0.08$ & $1.41 \pm 0.09$ \\
\hline Ae. bromeliifolia & $0.73 \pm 0.04$ & $0.22 \pm 0.10$ & $0.95 \pm 0.21$ & $1.11 \pm 0.11$ & $2.06 \pm 0.24$ \\
\hline Ae. distichantha & $0.43 \pm 0.08$ & $0.51 \pm 0.09$ & $0.94 \pm 0.13$ & $0.71 \pm 0.10$ & $1.69 \pm 0.19$ \\
\hline Ae. fasciata & $0.56 \pm 0.16$ & $0.37 \pm 0.09$ & $0.93 \pm 0.18$ & $1.07 \pm 0.06$ & $2.00 \pm 0.20$ \\
\hline Ae. nudicaulis & $0.93 \pm 0.12$ & $0.69 \pm 0.11$ & $1.62 \pm 0.17$ & $1.14 \pm 0.09$ & $2.76 \pm 0.21$ \\
\hline Ananas sp. & $0.56 \pm 0.09$ & $0.22 \pm 0.04$ & $0.77 \pm 0.07$ & $1.79 \pm 0.15$ & $2.50 \pm 0.14$ \\
\hline An. ananassoides & $0.54 \pm 0.07$ & $0.23 \pm 0.06$ & $0.77 \pm 0.07$ & $1.72 \pm 0.15$ & $2.50 \pm 0.14$ \\
\hline An. bracteatus & $0.78 \pm 0.08$ & $0.27 \pm 0.07$ & $1.04 \pm 0.08$ & $1.37 \pm 0.10$ & $2.41 \pm 0.15$ \\
\hline An. lucidus & $0.38 \pm 0.05$ & $0.20 \pm 0.04$ & $0.58 \pm 0.07$ & $1.54 \pm 0.15$ & $2.12 \pm 0.14$ \\
\hline An. parguazensis & $0.62 \pm 0.06$ & $0.31 \pm 0.08$ & $0.93 \pm 0.11$ & $1.04 \pm 0.13$ & $1.97 \pm 0.19$ \\
\hline Alcantarea nahoumii & $0.86 \pm 0.18$ & $1.89 \pm 0.22$ & $2.75 \pm 0.25$ & $0.70 \pm 0.24$ & $3.45 \pm 0.36$ \\
\hline Pseudananas sagenarius & $0.91 \pm 0.11$ & $0.28 \pm 0.03$ & $1.19 \pm 0.10$ & $1.98 \pm 0.18$ & $3.17 \pm 0.14$ \\
\hline Vriesea carinata & $0.47 \pm 0.08$ & $0.51 \pm 0.09$ & $0.98 \pm 0.13$ & $0.72 \pm 0.10$ & $1.70 \pm 0.19$ \\
\hline V. friburgensis & $0.47 \pm 0.11$ & $1.17 \pm 0.17$ & $1.63 \pm 0.15$ & $0.98 \pm 0.17$ & $2.62 \pm 0.25$ \\
\hline V. michaelii & $0.35 \pm 0.06$ & $0.87 \pm 0.11$ & $1.22 \pm 0.11$ & $0.46 \pm 0.06$ & $1.68 \pm 0.11$ \\
\hline V. paraibica & $0.35 \pm 0.07$ & $0.85 \pm 0.09$ & $1.20 \pm 0.10$ & $0.96 \pm 0.14$ & $2.16 \pm 0.16$ \\
\hline V. simplex & $0.43 \pm 0.05$ & $0.66 \pm 0.09$ & $1.09 \pm 0.10$ & $0.78 \pm 0.08$ & $1.87 \pm 0.13$ \\
\hline V. unilateralis & $0.48 \pm 0.09$ & $1.21 \pm 0.19$ & $1.69 \pm 0.22$ & $2.31 \pm 0.24$ & $4.00 \pm 0.34$ \\
\hline
\end{tabular}



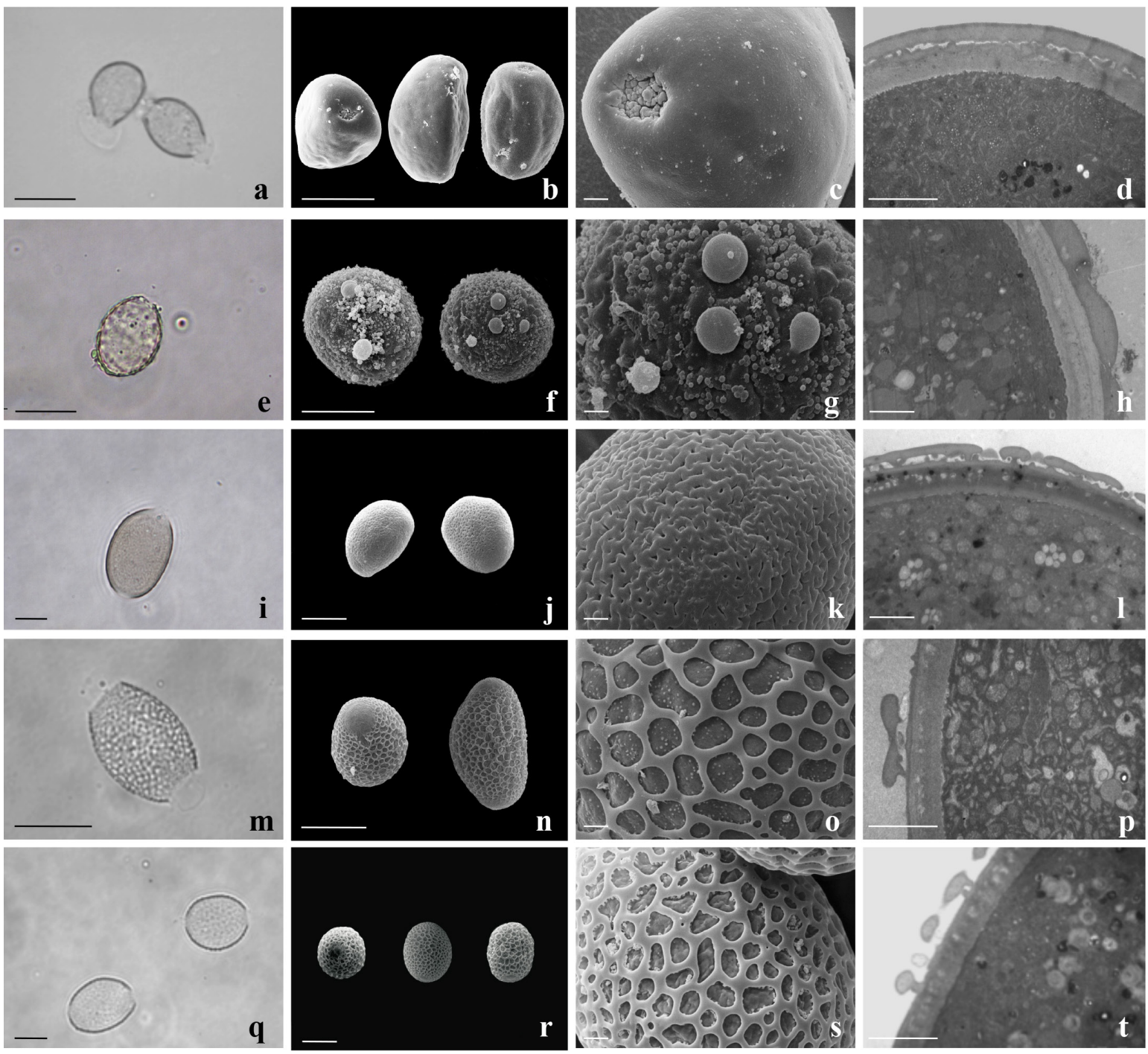

Figure 1 - Morphology and exine characteristics of pollen grains of Aechmea species. a-d) Ae. bicolor; e-h) Ae. bromeliifolia; i-l) Ae. distichantha; m-p) Ae. fasciata; q-t) Ae. nudicaulis; a, e, i, m, q) pollen after lactic acetolysis; b, f, j, n, r) polar and equatorial view; $\mathbf{c}, \mathbf{g}, \mathbf{k}, \mathbf{o}, \mathbf{s}$ ) detail of the ornamentation of the exine; $\mathbf{d}, \mathbf{h}, \mathbf{l}, \mathbf{p}, \mathbf{t}$ ) detail of grain wall; $\mathbf{a}, \mathbf{e}, \mathbf{i}, \mathbf{m}, \mathbf{q}$ ) images obtained by light microscopy, lactic acetolysis; $\mathbf{b}, \mathbf{c}, \mathbf{f}, \mathbf{g}, \mathbf{j}, \mathbf{k}, \mathbf{n}, \mathbf{o}, \mathbf{r}, \mathbf{s})$ scanning electron microscopy; $\mathbf{d}, \mathbf{h}, \mathbf{l}, \mathbf{p}, \mathbf{t})$ transmission electronic microscopy. Bars: $\mathbf{a}, \mathbf{e}, \mathbf{i}, \mathbf{m}, \mathbf{q}=50 \mu \mathrm{m} ; \mathbf{b}, \mathbf{f}, \mathbf{j}, \mathbf{n}, \mathbf{r}=20 \mu \mathrm{m} ; \mathbf{c}, \mathbf{d}, \mathbf{g}, \mathbf{h}, \mathbf{k}, \mathbf{l}, \mathbf{o}, \mathbf{p}, \mathbf{s}, \mathbf{t}=2 \mu \mathrm{m}$.

verrucate (Figure 1e-h). Ae. distichantha: medium pollen, bilateral symmetry, oblate shape, diporate, with a more convex side and the other flatter, tectate exine, rugulate with perforations (Figure 1i-1). Ae. fasciata: large pollen, bilateral symmetry, oblate shape, diporate, semitectate exine, reticulate, lumens ranging from round to polygonal, with granulations (Figure 1m-p). Ae. nudicaulis: medium pollen, bilateral symmetry, oblate shape, diporate, semitectate exine, reticulate, sparsely drilled walls, lumens ranging from round to polygonal, without granulations (Figure 1q-t).

\section{GENERA Ananas AND Pseudananas}

The Ananas pollen grains were medium sized and Pseudananas sagenarius presented large pollen. The two species had pollen with bilateral symmetry, oblate shape, diporate, semitectate exine, reticule with an alveolus format (for An. parguazensis), with 

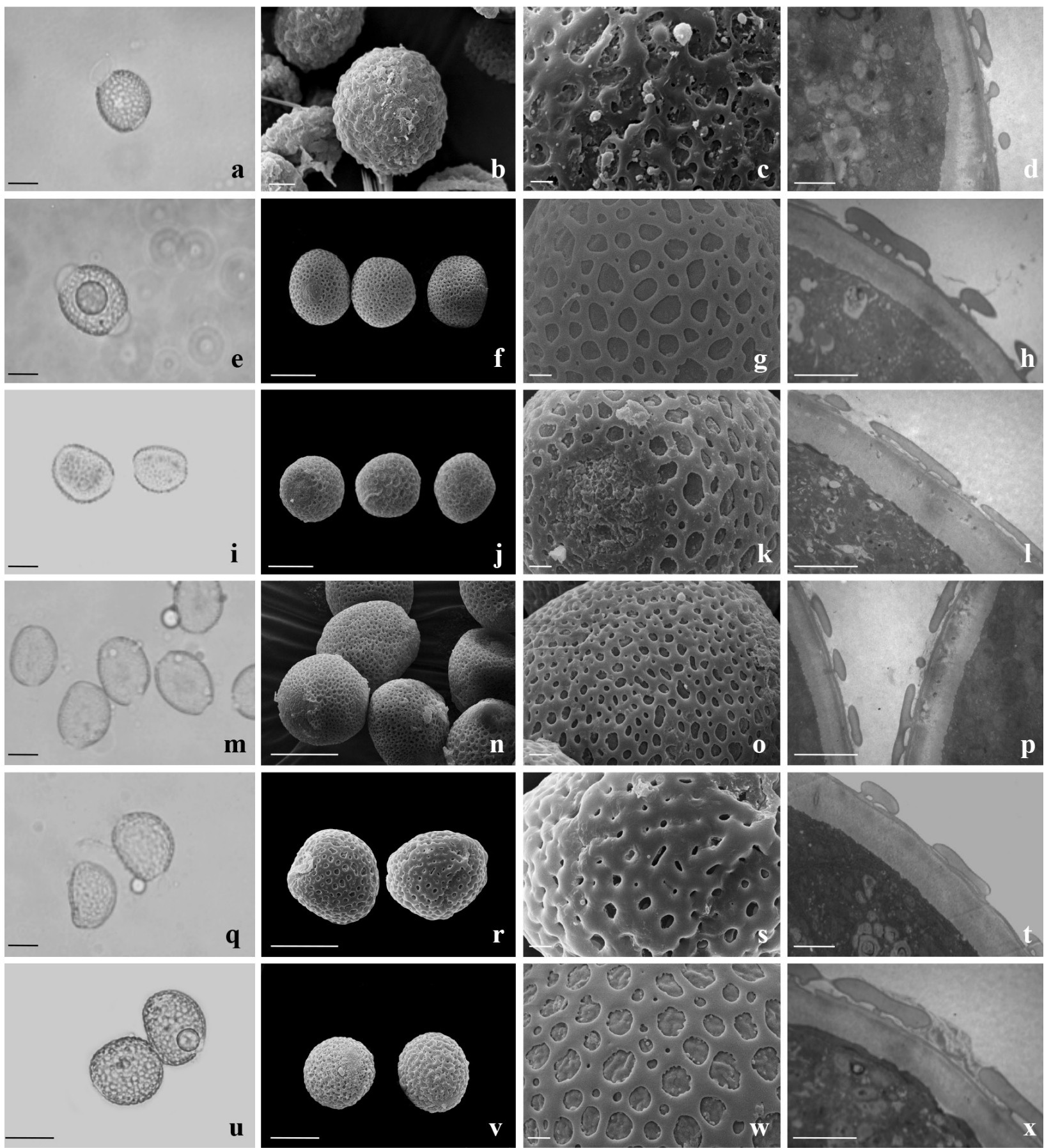

Figure 2 - Morphology and exine characteristics of pollen grains of Ananas and Pseudananas species. a-d) Ananas sp.; e-h) An. ananassoides; i-l) An. bracteatus; m-p) An. lucidus; q-t) An. parguazensis; u-x) P. sagenarius; a, e, i, m, q, u) pollen after lactic acetolysis; $\mathbf{b}, \mathbf{f}, \mathbf{j}, \mathbf{n}, \mathbf{r}, \mathbf{v})$ polar and equatorial view; $\mathbf{c}, \mathbf{g}, \mathbf{k}, \mathbf{0}, \mathbf{s}, \mathbf{w})$ detail of the ornamentation of the exine; d, h, l, p, t, x) detail of grain wall; a, e, i, m, q, u) images obtained by light microscopy, lactic acetolysis; $\mathbf{b}, \mathbf{c}, \mathbf{f}, \mathbf{g}, \mathbf{j}, \mathbf{k}, \mathbf{n}, \mathbf{o}, \mathbf{r}, \mathbf{s}, \mathbf{v}, \mathbf{w})$ scanning electron microscopy; $\mathbf{d}, \mathbf{h}, \mathbf{l}, \mathbf{p}, \mathbf{t}, \mathbf{x})$ transmission electronic microscopy. Bars: $\mathbf{a}, \mathbf{b}, \mathbf{e}, \mathbf{f}, \mathbf{i}, \mathbf{j}, \mathbf{m}, \mathbf{n}, \mathbf{q}, \mathbf{r}, \mathbf{u}, \mathbf{v}=20 \mu \mathrm{m} ; \mathbf{c}, \mathbf{d}, \mathbf{g}, \mathbf{h}, \mathbf{k}, \mathbf{l}, \mathbf{0}, \mathbf{p}$, $\mathbf{s}, \mathbf{t}, \mathbf{w}, \mathbf{x}=2 \mu \mathrm{m}$. 

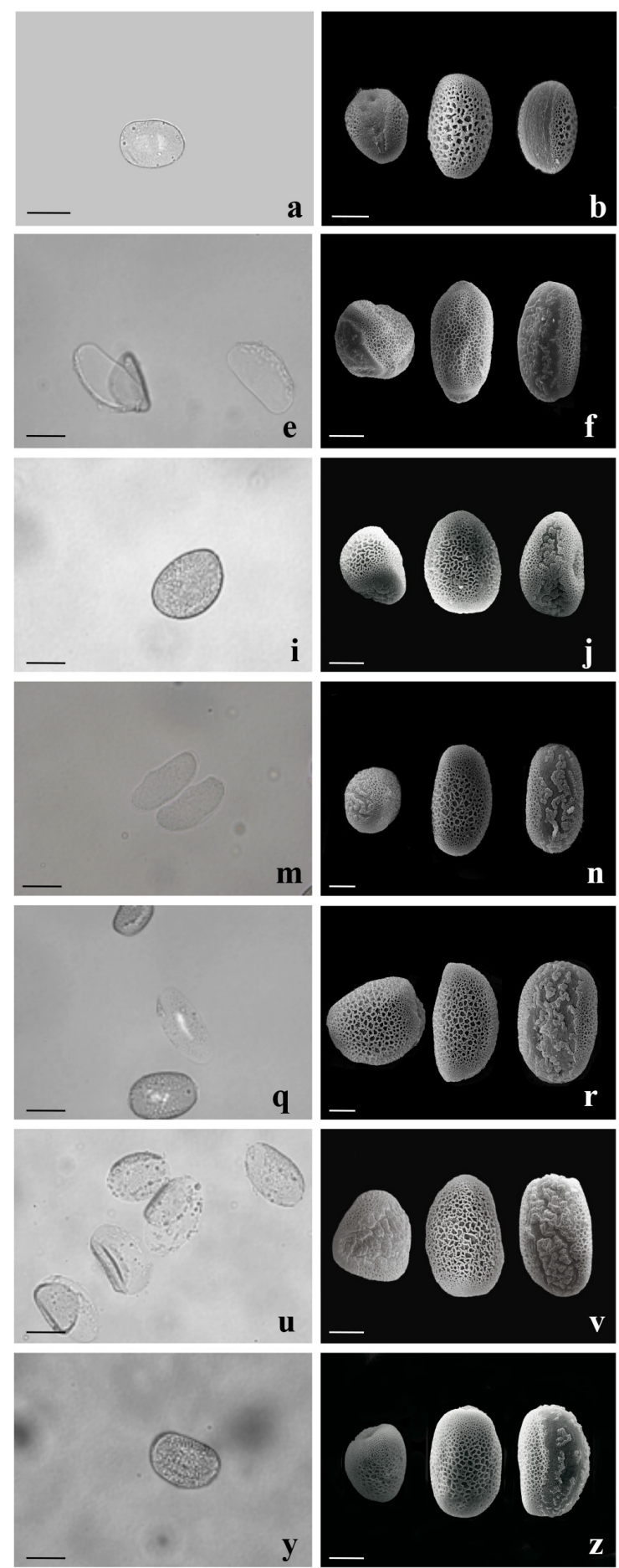
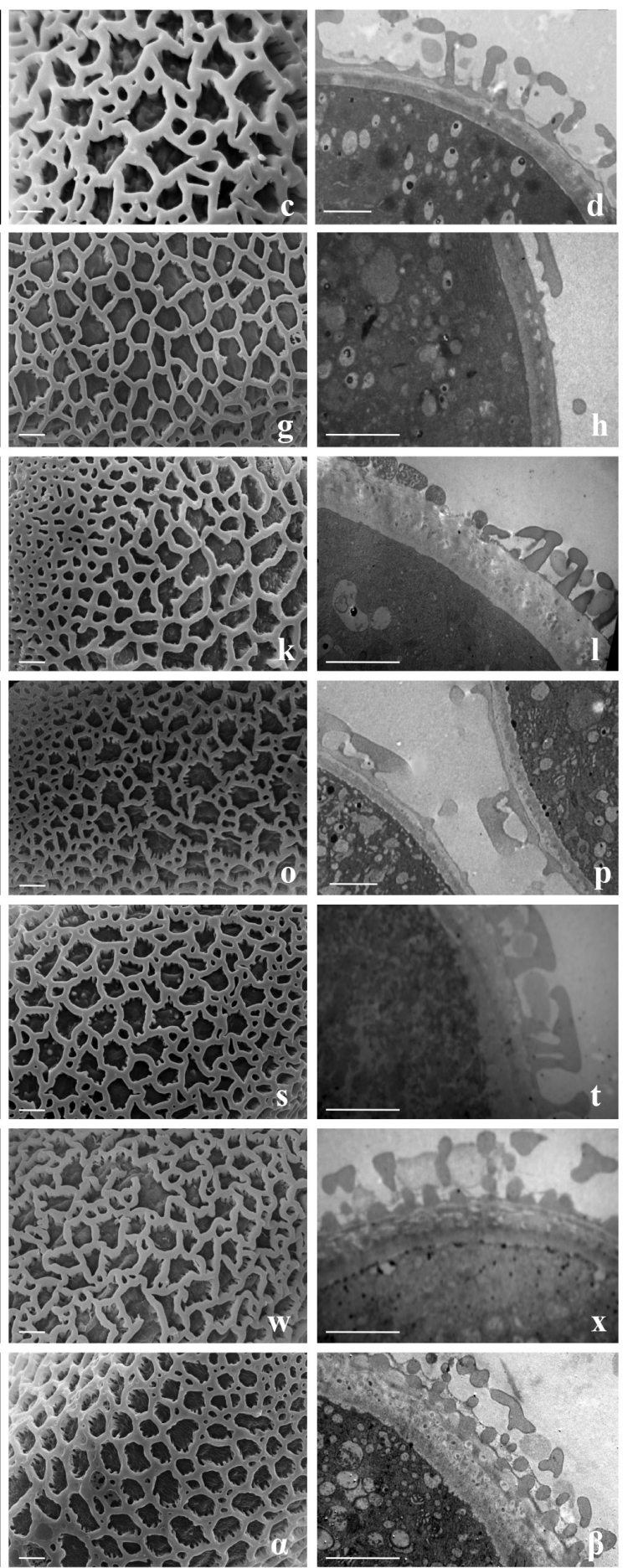

Figure 3 - Morphology and exine characteristics of Alcantarea nahoumii and Vriesea pollen grains. a-d) Al. nahoumii; e-h) V. carinata; i-l) V. friburgensis; m-p) V. michaelii; q-t) V. paraibica; u-x) V. simplex; y-z-o-乃) V. unilateralis; $\mathbf{a}, \mathbf{e}, \mathbf{i}, \mathbf{m}, \mathbf{q}, \mathbf{u}, \mathbf{y})$ pollen after lactic acetolysis; $\mathbf{b}, \mathbf{f}, \mathbf{j}, \mathbf{n}, \mathbf{r}, \mathbf{v}, \mathbf{z})$ polar and equatorial view; $\mathbf{c}, \mathbf{g}, \mathbf{k}, \mathbf{o}, \mathbf{s}, \mathbf{w}, \boldsymbol{\alpha})$ detail of the ornamentation of the exine; $\mathbf{d}, \mathbf{h}, \mathbf{l}, \mathbf{p}, \mathbf{t}, \mathbf{x}, \mathbf{B})$ detail of grain wall; $\mathbf{a}, \mathbf{e}, \mathbf{i}, \mathbf{m}, \mathbf{q}, \mathbf{u}, \mathbf{y}$ ) images obtained by light microscopy, lactic acetolysis; $\mathbf{b}, \mathbf{c}, \mathbf{f}, \mathbf{g}, \mathbf{j}, \mathbf{k}, \mathbf{n}, \mathbf{o}, \mathbf{r}, \mathbf{s}, \mathbf{v}, \mathbf{w}, \mathbf{z}, \boldsymbol{\alpha})$ scanning electron microscopy; $\mathbf{d}, \mathbf{h}, \mathbf{l}, \mathbf{p}, \mathbf{t}, \mathbf{x}, \mathbf{\beta})$ transmission electronic microscopy. Bars: $\mathbf{a}, \mathbf{e}, \mathbf{i}, \mathbf{m}, \mathbf{q}, \mathbf{u}, \mathbf{y}=50 \mu \mathrm{m} ; \mathbf{b}, \mathbf{f}, \mathbf{j}, \mathbf{n}, \mathbf{r}, \mathbf{v}, \mathbf{z}=20 \mu \mathrm{m} ; \mathbf{c}, \mathbf{d}, \mathbf{g}, \mathbf{h}, \mathbf{k}, \mathbf{l}, \mathbf{o}, \mathbf{p}, \mathbf{s}$, $\mathbf{t}, \mathbf{w}, \mathbf{x}, \alpha, \mathbf{B}=2 \mu \mathrm{m}$. 
perforations, lumens with contour ranging from round to polygonal, with granulations (Figure 2).

\section{GENUS Alcantarea}

The pollen of Al. nahoumii were large, with bilateral symmetry, elliptic shape, with an equatorial boundary, being plane on one side and convex on the other, monocolpate with irregular contour, approximately the same length as polar diameter or larger, semitectate exine, reticulate, with meshes smaller towards the colpus and the tips, heterobrochate, without granulations, lumens ranging from round to polygonal (Figure 3a-d).

\section{GENUS Vriesea}

Except for $V$. carinata, which presented very large pollen grains, all the other Vriesea species presented large pollen grains, bilateral symmetry, elliptic shape, equatorially present boundary plane on one side and convex on the other, monocolpate with irregular contour, about the same length as the equatorial diameter or larger, semitectate exine, reticulate, with smaller mesh towards the colpus and the tips, heterobrochate, with granulations and, lumens ranging from round to polygonal (Figure $3 e-z, \alpha-\beta)$.

\section{In vitro POLLEN GERMINATION}

Statistical analysis showed significant interaction between the different germination media and the species studied, for the percentage of in vitro germination and pollen tube length (Table III).

After 24 hours of incubation, in general BKM and SM media resulted in higher germination and pollen tube length for all species. The BM medium was low efficient for germination: pollen of only eight species germinated on this media, with values lower than 39\% (Table III). Among the Vriesea species, $V$. simplex, V. michaelii and $V$. friburgensis presented the best results when germinated in BKM and SM media.
The pollen tube length was also variable, depending on the species and germination media (Table III, Figure 4a-b). Ae. fasciata presented the highest values in BKM and SM media, averaging $1.14 \mathrm{~mm}$ (Figure 4a), while the lowest values were obtained in BM medium for all species studied (Table III, Figure 4b).

\section{HISTOCHEMICAL ANALYSIS OF POLLEN VIABILITY}

Histochemical tests showed high pollen viability rates for most of the species studied using the three stains, with most values greater than $70 \%$ and the best rate being $100 \%$ for An. lucidus by acetocarmine and Sudan IV staining (Figure 4c-e). In contrast, Ananas sp. showed low viability, with values lower than $40 \%$ for all three stains (Table IV).

\section{DISCUSSION}

\section{POLLEN GRAINS MORPHOLOGY}

The morphology of the pollen grains of the bromeliad species varied in type of aperture (colpate and porate), size, and exine ornamentation. The observed characteristics are in accordance with the literature for the family Bromeliaceae (Mez 1891-1894, Wanderley and Melhem 1991, Vervaecke et al. 2003, Moreira et al. 2005, Silva et al. 2016). The characteristics of the species of the genus Vriesea were in accordance with Halbritter (1992), who stated that the species of the subfamily Tillandsioideae generally present monocolpate pollen, with little morphological variation. The results observed in this study were consistent with the observations of acetolyzed pollen reported by Moreira et al. (2005).

Moreira et al. (2005), working with species of the genera Neoregelia and Nidularium, subfamily Bromelioideae, described the exine with thickness between 4.28 to 4.67 micrometers, larger than those observed for the genera Aechmea and Ananas 
TABLE III

In vitro germination (\%) and pollen tube length $(\mathrm{mm})$ in Bromeliaceae of the genera Aechmea, Ananas, Alcantarea, Pseudananas, and Vriesea, on four germination media.

\begin{tabular}{|c|c|c|c|c|}
\hline \multirow{3}{*}{ Species } & \multicolumn{4}{|c|}{ Germination media $^{a}$} \\
\hline & BM & BKM & MBКМ & SM \\
\hline & \multicolumn{4}{|c|}{ In vitro germination (\%) } \\
\hline Aechmea bicolor & $0.00 \mathrm{eD}$ & $61.66 \mathrm{~dB}$ & $39.66 \mathrm{cC}$ & $91.00 \mathrm{aA}$ \\
\hline Ae. bromeliifolia & $0.57 \mathrm{eD}$ & $82.67 \mathrm{bA}$ & $36.33 \mathrm{cC}$ & $72.33 \mathrm{cB}$ \\
\hline Ae. distichantha & $29.60 \mathrm{bC}$ & $90.60 \mathrm{aA}$ & $53.23 \mathrm{bB}$ & $88.73 \mathrm{aA}$ \\
\hline Ae. fasciata & $39.00 \mathrm{aC}$ & $70.16 \mathrm{cA}$ & $57.83 \mathrm{aB}$ & $77.03 \mathrm{bA}$ \\
\hline Ae. nudicaulis & $12.00 \mathrm{cD}$ & $80.33 \mathrm{bA}$ & $29.00 \mathrm{dC}$ & $58.66 \mathrm{~dB}$ \\
\hline Ananas sp. & $0.00 \mathrm{eB}$ & $22.33 \mathrm{fA}$ & $19.66 \mathrm{eA}$ & $29.27 \mathrm{eA}$ \\
\hline An. ananassoides & $0.00 \mathrm{eD}$ & $71.16 \mathrm{cA}$ & $38.36 \mathrm{cB}$ & $77.86 \mathrm{bA}$ \\
\hline An. bracteatus & $2.66 \mathrm{dD}$ & $85.67 \mathrm{aA}$ & $42.67 \mathrm{cC}$ & $63.33 \mathrm{~dB}$ \\
\hline An. lucidus & $2.33 \mathrm{dD}$ & $85.66 \mathrm{aA}$ & $55.33 \mathrm{aC}$ & $73.33 \mathrm{cB}$ \\
\hline An. parguazensis & $0.00 \mathrm{eC}$ & $69.66 \mathrm{cA}$ & $42.67 \mathrm{cB}$ & $67.66 \mathrm{cA}$ \\
\hline Alcantarea nahoumii & $1.73 \mathrm{dC}$ & $47.67 \mathrm{eB}$ & $31.00 \mathrm{~dB}$ & $74.00 \mathrm{cA}$ \\
\hline Pseudananas sagenarius & $0.00 \mathrm{eD}$ & $80.00 \mathrm{bA}$ & $51.66 \mathrm{bC}$ & $68.33 \mathrm{cB}$ \\
\hline Vriesea carinata & $0.00 \mathrm{eD}$ & $74.33 \mathrm{cB}$ & $55.33 \mathrm{aC}$ & $80.33 \mathrm{bA}$ \\
\hline V. friburgensis & $0.12 \mathrm{eC}$ & $90.43 \mathrm{aA}$ & $59.93 \mathrm{aB}$ & $87.93 \mathrm{aA}$ \\
\hline V. michaelii & $0.00 \mathrm{eD}$ & $77.67 \mathrm{bB}$ & $47.67 \mathrm{bC}$ & $90.03 \mathrm{aA}$ \\
\hline V. paraibica & $0.00 \mathrm{eC}$ & $80.00 \mathrm{bA}$ & $40.20 \mathrm{cB}$ & $88.73 \mathrm{aA}$ \\
\hline$V$. simplex & $0.00 \mathrm{eD}$ & $80.73 \mathrm{bB}$ & $60.60 \mathrm{aC}$ & $90.46 \mathrm{aA}$ \\
\hline V. unilateralis & $0.00 \mathrm{eC}$ & $81.33 \mathrm{bA}$ & $41.00 \mathrm{cB}$ & $86.33 \mathrm{aA}$ \\
\hline \multirow[t]{2}{*}{$\mathrm{CV}(\%)$} & \multicolumn{4}{|c|}{6.90} \\
\hline & \multicolumn{4}{|c|}{ Pollen tube length $(\mathrm{mm})^{\mathrm{b}}$} \\
\hline Aechmea bicolor & $0.00 \mathrm{cC}$ & $0.30 \mathrm{hA}$ & $0.12 \mathrm{fB}$ & $0.24 \mathrm{fA}$ \\
\hline Ae. bromeliifolia & $0.19 \mathrm{bD}$ & $0.72 \mathrm{eA}$ & $0.53 \mathrm{bC}$ & $0.61 \mathrm{~dB}$ \\
\hline Ae. distichantha & $0.24 \mathrm{aD}$ & $0.86 \mathrm{dA}$ & $0.57 \mathrm{bC}$ & $0.65 \mathrm{~dB}$ \\
\hline Ae. fasciata & $0.29 \mathrm{aB}$ & $1.14 \mathrm{bA}$ & $0.48 \mathrm{cB}$ & $1.13 \mathrm{aA}$ \\
\hline Ae. nudicaulis & $0.12 \mathrm{bD}$ & $1.04 \mathrm{bA}$ & $0.38 \mathrm{dC}$ & $0.72 \mathrm{cB}$ \\
\hline Ananas sp. & $0.00 \mathrm{cC}$ & $0.48 \mathrm{gA}$ & $0.33 \mathrm{~dB}$ & $0.50 \mathrm{eA}$ \\
\hline An. ananassoides & $0.00 \mathrm{cC}$ & $0.54 \mathrm{fB}$ & $0.73 \mathrm{aA}$ & $0.73 \mathrm{cA}$ \\
\hline An. bracteatus & $0.09 \mathrm{cC}$ & $1.07 \mathrm{bA}$ & $0.55 \mathrm{bB}$ & $0.46 \mathrm{eB}$ \\
\hline An. lucidus & $0.05 \mathrm{cC}$ & $1.09 \mathrm{bA}$ & $0.48 \mathrm{cB}$ & $0.52 \mathrm{eB}$ \\
\hline An. parguazensis & $0.00 \mathrm{cC}$ & $0.89 \mathrm{dA}$ & $0.47 \mathrm{cB}$ & $0.51 \mathrm{eB}$ \\
\hline Alcantarea nahoumii & $0.03 \mathrm{cC}$ & $0.28 \mathrm{hB}$ & $0.24 \mathrm{eB}$ & $0.55 \mathrm{eA}$ \\
\hline Pseudananas sagenarius & $0.00 \mathrm{cD}$ & $1.12 \mathrm{bA}$ & $0.71 \mathrm{aB}$ & $0.59 \mathrm{dC}$ \\
\hline Vriesea carinata & $0.00 \mathrm{cC}$ & $0.77 \mathrm{eA}$ & $0.34 \mathrm{~dB}$ & $0.61 \mathrm{dA}$ \\
\hline V. friburgensis & $0.01 \mathrm{cD}$ & $1.09 \mathrm{aA}$ & $0.44 \mathrm{eC}$ & $0.72 \mathrm{cB}$ \\
\hline V. michaelii & $0.00 \mathrm{cC}$ & $0.83 \mathrm{dA}$ & $0.35 \mathrm{~dB}$ & $0.85 \mathrm{bA}$ \\
\hline$V$. paraibica & $0.00 \mathrm{cD}$ & $0.60 \mathrm{fB}$ & $0.23 \mathrm{eC}$ & $0.87 \mathrm{bA}$ \\
\hline V. simplex & $0.00 \mathrm{cC}$ & $0.96 \mathrm{cA}$ & $0.43 \mathrm{cB}$ & $0.88 \mathrm{bA}$ \\
\hline V. unilateralis & $0.00 \mathrm{cC}$ & $0.71 \mathrm{eA}$ & $0.36 \mathrm{~dB}$ & $0.66 \mathrm{dA}$ \\
\hline CV (\%) & & & & \\
\hline
\end{tabular}

Footnotes: ${ }^{\text {a }}=$ Germination media: BM (Parton et al. 2002), BKM (Brewbaker and Kwack 1963), MBKM (Brewbaker and Kwack 1963, modified), SM (Soares et al. 2008). ${ }^{b}$ The results correspond to the average pollen tube length of 60 grains, 24 hours after inoculation on germination media. Averages followed by the same lower-case letter in the column and capital letter in the line do not differ by the Scott-Knott test at 1\% probability. 

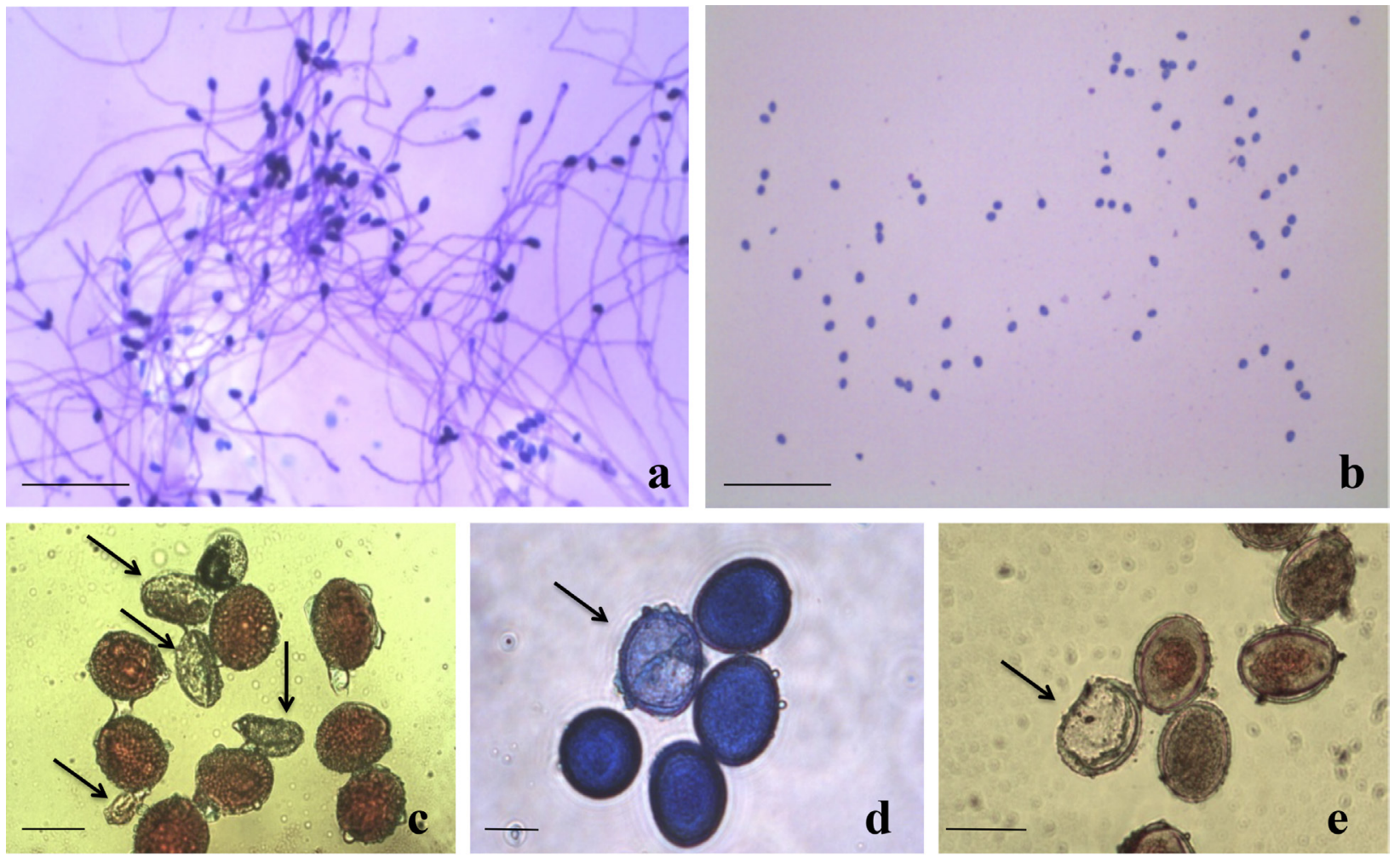

Figure 4 - In vitro germination and histochemical test of Bromeliaceae pollen grains. a-b) Pollen germination of Bromeliaceae species. a) Ae. fasciata in BKM medium, showing greater pollen tube length; b) Aechmea bicolor in BM medium, showing lack of pollen germination; c-e) Viability by histochemical test of pollen. c) Ae. fasciata pollen stained with acetocarmine (1\%); d) Ae. nudicaulis pollen stained with Alexander's solution plus 2\% lactic acid; e) Ae. distichantha pollen stained with Sudan IV (1\%). $($ arrows $=$ unviable pollen). BM (Parton et al. 2002), BKM (Brewbaker and Kwack 1963). Bars: $\mathbf{a}-\mathbf{b}=0.5 \mathrm{~mm} ; \mathbf{c}, \mathbf{e}=50 \mu \mathrm{m} ; \mathbf{d}=$ $20 \mu \mathrm{m}$.

in this study and similar in size to those found for the genus Vriesea of the subfamily Tillandsioideae. However, the pollen grains presented in both reports all fell into the same class, i.e., from medium to large.

According to Benzing (2000), the use of pollen morphology characteristics for taxonomic studies is an alternative to the use of other characteristics, such as leaf and flower color and size of structures, which are more subject to change compared to the characteristics of pollen grains.

The number of pollen grains produced per flower varied considerably between genera and in some cases between species of the same genus (Table I). The variation in the evaluated species corroborated the results found by Hmeljevski et al. (2007), who studied Dyckia ibiramensis and obtained an average of 54,675 grains, while Rogalski et al. (2009) counted an average of 70,700 grains for Dyckia brevifolia, highlighting a significant variation between two species of the same genus. The production of pollen together with viability and other factors directly influence the success of fertilization, generating more seeds (Smith et al. 2009). The number of flowers per inflorescence is quite variable within the Bromeliaceae family. This will directly influence reproduction, pollination syndrome and species breeding programs.

\section{In vitro POLLEN GERMINATION}

In general, BKM and SM media produced the highest germination rates and pollen tube length for all species. The BM medium (Parton et al. 2002) developed for bromeliads of the genera 
TABLE IV

Viability by histochemical test of pollen grains (\%) in Bromeliaceae species of the genera Aechmea, Ananas, Alcantarea, Pseudananas, and Vriesea.

\begin{tabular}{lccc}
\hline \multirow{2}{*}{ Species } & \multicolumn{3}{c}{ Histochemical test } \\
\cline { 2 - 4 } Aechmea bicolor & Alexander 2\% & Acetocarmine 1\% & Sudan IV 1\% \\
Ae. bromeliifolia & $90.33 \mathrm{aA}$ & $94.33 \mathrm{aA}$ & $95.00 \mathrm{aA}$ \\
Ae. distichantha & $80.33 \mathrm{bB}$ & $87.43 \mathrm{aA}$ & $88.33 \mathrm{aA}$ \\
Ae. fasciata & $81.50 \mathrm{bB}$ & $83.00 \mathrm{bB}$ & $89.00 \mathrm{aA}$ \\
Ae. nudicaulis & $75.67 \mathrm{bB}$ & $75.63 \mathrm{bB}$ & $89.67 \mathrm{aA}$ \\
Ananas sp. & $83.67 \mathrm{bA}$ & $89.67 \mathrm{aA}$ & $94.00 \mathrm{aA}$ \\
An. ananassoides & $27.33 \mathrm{cB}$ & $35.32 \mathrm{cA}$ & $40.00 \mathrm{bA}$ \\
An. bracteatus & $87.00 \mathrm{aA}$ & $88.23 \mathrm{aA}$ & $91.00 \mathrm{aA}$ \\
An. lucidus & $82.67 \mathrm{bB}$ & $89.67 \mathrm{aA}$ & $93.67 \mathrm{aA}$ \\
An. parguasensis & $96.67 \mathrm{aA}$ & $100.00 \mathrm{aA}$ & $100.00 \mathrm{aA}$ \\
Alcantarea nahoumii & $81.00 \mathrm{bB}$ & $88.67 \mathrm{aA}$ & $93.00 \mathrm{aA}$ \\
Pseudananas sagenarius & $70.33 \mathrm{bC}$ & $78.67 \mathrm{bB}$ & $87.67 \mathrm{aA}$ \\
Vriesea carinata & $97.67 \mathrm{aA}$ & $99.67 \mathrm{aA}$ & $100.00 \mathrm{aA}$ \\
V. friburgensis & $88.67 \mathrm{aA}$ & $89.67 \mathrm{aA}$ & $94.33 \mathrm{aA}$ \\
V. michaelii & $90.57 \mathrm{aA}$ & $91.93 \mathrm{aA}$ & $94.00 \mathrm{aA}$ \\
V. paraibica & $89.67 \mathrm{aA}$ & $93.00 \mathrm{aA}$ & $94.00 \mathrm{aA}$ \\
V. simplex & $84.17 \mathrm{bA}$ & $85.50 \mathrm{bA}$ & $90.67 \mathrm{aA}$ \\
V. unilateralis & $89.00 \mathrm{aA}$ & $78.40 \mathrm{bB}$ & $91.67 \mathrm{aA}$ \\
CV (\%) & $84.33 \mathrm{bA}$ & $83.70 \mathrm{bA}$ & $89.00 \mathrm{aA}$ \\
\hline Fotnos:The & & 8.23 & \\
\hline
\end{tabular}

Footnotes: The results correspond to a total count of 300 pollen grains obtained from three individual flowers from three different plants. Same lowercase letters in the column and uppercase letters in the row do not differ by the Scott-Knott test at $1 \%$ probability.

Aechmea, Vriesea, Guzmania and Tillandsia, was not efficient for germination. The presence of calcium, magnesium, potassium nitrate and lower sucrose concentrations seem to be fundamental in promoting germination of pollen of the species studied.

In vitro germination, despite the advantage of controlling the experimental conditions, does not completely reproduce pollen tube growth in vivo, since interactions may occur between the composition of the germination medium and the various plant material and environmental conditions. However, despite these drawbacks, in vitro germination simulates the closest condition to in planta pollen germination (Soares et al. 2013) and has been considered a very useful methodology for this purpose.

The results obtained in this study were different from those obtained by Parton et al. (2002) for the species Ae. fasciata, Ae. chantinii, Vriesea 'Cristiane', V. splendens, Guzmania lingulata and Tillandsia cyanea. They obtained the best results using BM medium, in comparison with BKM and MBKM media. This supports the need to adapt these protocols for each species. Some authors consider that the germination media should include, in addition to carbohydrates, elements such as boric acid, calcium nitrate, potassium nitrate and magnesium sulfate (Taylor and Hepler 1997).

According to Pfahler et al. (1997), boron maximizes germination and the responses vary 
according to the species. Its mechanism of action is to interact with sugar and form an ionized sugarborate complex, which reacts more quickly with cell membranes. Thompson and Batjer (1950) found increased germination percentage and greater pollen tube length of various temperate fruit species with the addition of boron to germination media. However, the results of this study highlight the need to add other elements to germination media. Addition of calcium, for example, can provide physiological conditions with lower permeability, linear growth and rigid pollen tube (Bhojwani and Bhatnagar 1974).

\section{HISTOCHEMICAL ANALYSIS OF POLLEN VIABILITY}

The histochemical results in general presented overestimated values, when compared to pollen germination in vitro, for most species studied. Similar findings were reported by Soares et al. (2011) in six accessions of ornamental pineapple, with overestimated histochemical pollen viability results. However, in our study, Ananas sp. showed lower viability for all three stains, in accordance with observations by scanning electron microscopy, where a large percentage of malformed grains was observed. This accession of Ananas sp. is undergoing other molecular, morphological and reproductive studies to identify its real taxonomy.

According to Parfitt and Ganeshan (1989), staining with acetocarmine to check pollen viability does not produce reliable results. They observed that heat-killed Prunus pollen was highly stained. Kearns and Inouye (1993) reported that histochemical tests are used to indicate pollen viability, but these tests reflect only the integrity of cell structures. Acetocarmine indicates the chromosomal integrity (Kearns and Inouye 1993), Sudan IV the presence of lipids (Baker and Baker 1979) and Alexander's solution contains acidic fuchsin and green malachite, which react with the protoplasm and the cell wall cellulose of pollen (Alexander 1980).

For a more successful pollination, it is important for the two factors (germination and pollen tube length), to be as large as possible, increasing the likelihood that the gametes will meet (Soares et al. 2008). Thus, the establishment of efficient germination media is important, since knowledge of the germination rate and pollen viability are important for planning genetic improvement programs aimed at producing hybrids.

On the other hand, for pollen conservation, the development of a method that permits viability testing before and after storage is important for the use of this strategy, and germination in culture media is easy and can be used routinely.

Thus, the results of this study contribute to the characterization of the bromeliad species studied, and can support the conservation and genetic improvement of these species, with substantial gains in both areas.

\section{CONCLUSIONS}

Variations in shape and size were observed in pollen morphology among the studied species. Aechmea and Ananas presented medium sized pollen, except for Ae. fasciata. Al nahoumii and Pseudananas sagenarius, and species of Vriesea showed large pollen, with the exception of $V$. carinata, with very large pollen.

Aechmea, Ananas and P. sagenarius pollen have bilateral symmetry, oblate shape, diporate with exine ranging from tectate to semitectate. Al. nahoumii and Vriesea species have pollen monocolpate, with bilateral symmetry, elliptic shape, with semitectate, reticulate, heterobrochate exine.

The pollen of the species studied showed high germination rates and pollen tube length, except for the Ananas sp. accession. The use of different germination media and histochemical 
tests allowed for the definition of the MS and BKM media as the most suitable for bromeliads, and showed that all the stains present similar results. Studies of the morphology of pollen offer detailed characterization of the species, which can be important for taxonomy, improving the distinction of very similar species. On the other hand, studies of pollen viability can support conservation and genetic improvement of the species.

\section{ACKNOWLEDGMENTS}

The authors acknowledge the support of Fundação de Amparo à Pesquisa do Estado de São Paulo FAPESP (2009/18255-0), Conselho Nacional de Desenvolvimento Científico e Tecnológico - CNPq (305.785/2008-7 and 476.131/2008-1), Coordenação de Aperfeiçoamento de Pessoal de Nível Superior (PROCAD - 2013/ CAPESEmbrapa $\left.N^{\circ} 15 / 2014\right)$, and Embrapa Mandioca e Fruticultura (01.15.02.002.09.02.001), for financial support, and Núcleo de Apoio à Pesquisa em Microscopia Eletrônica na Pesquisa Agropecuária, Escola Superior de Agricultura "Luiz de Queiroz", Universidade de São Paulo, for the use of the microscopy facilities.

\section{REFERENCES}

ALEXANDER MP. 1980. A versatile stain for pollen fungi, yeast and bacteria. Stain Technol 55: 13-18

BAKER HG AND BAKER I. 1979. Starch in angiosperm pollen grains and its evolutionary significance. Am J Bot 66: 591-600

BARFUSS MHJ, SAMUEL R, TILL W AND STUESSY TF. 2005. Phylogenetic relationships in subfamily Tillandsioideae (Bromeliaceae) based on DNA sequence data from seven plastid regions. Am J Bot 92: 337-351.

BENZING DH. 2000. Bromeliaceae: Profile an Adaptive Radiation. Cambridge University Press, Cambridge, 690 p.

BHOJWANI SS AND BHATNAGAR SP. 1974. The embryology of angiosperms. Vikas Publishing House, New Delhi, 386 p.

BREWBAKER JL AND KWACK BH. 1963. The essential role of calcium ion in pollen germination and pollen tube growth. Am J Bot 50: 859-865
BUTCHER D AND GOUDA EJ. 2017. The New Bromeliad Taxon List. http://BromTaxonList.floraPix.nl. University Botanic Gardens, Utrecht (Accessed: September 6, 2017).

DAFNI A. 1992. Pollination ecology: a practical approach. University Press, New York, 250 p.

EHLER N AND SCHILL R. 1973. Die Pollen morphologie der Bromeliaceae. Pollen et Spores 15: 13-45.

ERDTMAN G AND PRAGLOWSKI K. 1974. A note on pollen morphology. Flora Neotropica 14: 28-33.

FORZZA RC ET AL. 2013. Bromeliaceae. In: Martinelli G and Moraes MA (Eds), Livro vermelho da flora do Brasil. Andrea Jakobsson \& Instituto de Pesquisas do Jardim Botânico do Rio de Janeiro, Rio de Janeiro, p. 315-397.

GIVNISH TJ ET AL. 2011. Phylogeny, adaptive radiation and historical biogeography in Bromeliaceae: Insights from an eight-locus plastid phylogeny. Am J Bot 98: 872-895.

GIVNISH TJ, MILLAM KC, BERRY PE AND SYTSMA KJ. 2007. Phylogeny, adaptive radiation, and historical biogeography of Bromeliaceae inferred from $n d h F$ sequence data. Aliso 23: 3-26.

GIVNISH TJ, MILLAM KC, EVANS TM, HALL JC, PIRES JC, BARRY PE AND SYTSAM KJ. 2004. Ancient vicariance or recent long-distance dispersal Inferences about phylogeny and south american-african disjunctionsin Rapateaceae and Bromeliaceae based on $n d h F$ sequence data. Int J Plant Sci 165: 35-54.

HALBRITTER H. 1992. Morphologie und Systematische Bedeutung des Pollens der Bromeliaceae. Grana 31: 197-212.

HALBRITTER H AND TILL W. 1998. Morfologia polínica do Complexo Nidularioide, In: Pereira MV (Ed), Bromélias da Mata Atlântica. Salamandra, Rio de Janeiro, p. 114-121.

HESSE M, HALBRITTER H, WEBER M, BUCHNER R, FROSCH-RADIVO A AND ULRICH S. 2009. Pollen terminology. An illustrated handbook. Springer, Wien, $266 \mathrm{p}$.

HMELJEVSKI KV, REIS A, REIS MS, ROGASLSKI JM, NETO CD AND LENZI M. 2007. Resultados preliminares da biologia reprodutiva de Dyckia ibiramensis Reitz (Bromeliaceae): uma espécie rara e endêmica de Santa Catarina. Rev Bras Biocienc 5: 267-269.

KARNOVSKY MJ. 1965. A formaldehyde-glutaraldehyde fixative in high osmolality for use in electron microscopy. J Cell Biol 27: 137-138A.

KEARNS CA AND INOUYE DW. 1993. Techniques for pollination biologist. University of Colorado, Niwot, $583 \mathrm{p}$.

KUMARI A, PAPENFUS HB, KULKARNI MG, POŠTA M AND VAN STADEN J. 2015. Effect of smoke derivatives on in vitro pollen germination and pollen tube elongation of species from different plant families. Plant Biol 17: 825-830.

MEZ C. 1891-1894. Bromeliaceae, In: Martius CFP et al. (Eds), Flora Brasiliensis. Lipsiae: Typographia Regia 3, p. 173-634. 
MEZ C. 1896. Bromeliacea, In: Candolle A and Candolle C (Eds), Monographiae Phanerogamarum: Prodromi, Paris, p. 1-990.

MOREIRA BA, CRUZ-BARROS MAV AND WANDERLEY MGL. 2005. Morfologia polínica de algumas espécies dos gêneros Neoregelia L.B. Sm. e Nidularium Lem. (Bromeliaceae) do Estado de São Paulo, Brasil. Acta Bot Bras 19: 61-70.

PALMA-SILVA C, SANTOS DG, KALTCHUK-SANTOS E AND BODANESE-ZANETTINI MH. 2004. Chromosome numbers, meiotic behavior, and pollen viability of species of Vriesea and Aechmea genera (Bromeliaceae) native to Rio Grande do Sul, Brazil. Am J Bot 91: 804-807.

PARFITT D AND GANESHAN S. 1989. Comparison of procedures for estimating viability of prunus pollen. Hortscience 24: 354-356.

PARTONE, VERVAEKER, DELENBR, VANDENBUSSCHE R AND DE PROFT M. 2002. Viability and storage of bromeliad pollen. Euphytica 125: 155-161.

PFAHLER PL, PEREIRA MJ AND BARNETT RD. 1997. Genetic variation for in vitro sesame pollen germination and tube growth. Theor Appl Genet 95: 1218-1222.

PUNT W, HOEN PP, BLACKMORE S, NILSSON S AND LE THOMAS A. 2007. Glossary of pollen and spore terminology. Rev Palaeobot Palyno 143: 1-81.

RASBAND WS. 1997-2012. ImageJ. U. S. National Institutes of Health, Bethesda, Maryland, USA.

RAYNAL A AND RAYNAL J. 1979. Une technique de préparation des grains de pollen fragiles. Adansonia 2: 77-79.

REYNOLDS ES. 1963. The use of lead citrate at high $\mathrm{pH}$ as an electron-opaque stain in electron microscopy. J Cell Biol 17: 208-212.

ROGALSKI JM, REIS A, REIS MS AND HMELJEVSKI KV. 2009. Biologia reprodutiva da reófita Dyckia brevifolia Baker (Bromeliaceae), no Rio Itajaí-Açu, Santa Catarina, Brasil. Rev Bras Bot 32: 691-702.

SAS INSTITUTE INC. 2004. SAS/Stat user's guide: statistics. Version 9.1.3 ed., Cary, NC.

SILVA VJD, RIBEIRO EM, LUIZI-PONZO A AND FARIA APF. 2016. Ultrastructure and pollen morphology of Bromeliaceae species from the Atlantic Rainforest in Southeastern Brazil. An Acad Bras Cienc 88: 439-449.

SMITH LB AND DOWNS RJ. 1974. Pitcairnioideae (Bromeliaceae. Part 1). Flora Neotropica Monog 14: $1-658$.

SMITH LB AND DOWNS RJ. 1977. Tillandsioideae (Bromeliaceae. Part 2). Flora Neotropica Monog 14: 6631492.

SMITH LB AND DOWNS RJ. 1979. Bromelioideae (Bromeliaceae. Part 3). Flora Neotropica Monog 14: 1493-2141.

SMITH M ET AL. 2009. Inuence of the North Atlantic Oscillation on grass pollen counts in Europe. Aerobiologia 25: 321-332.
SOARES TL, JESUS ON, SANTOS-SEREJO JA AND OLIVEIRA EJ. 2013. In vitro pollen germination and pollen viability in passion fruit (Passiflora spp.). Rev Bras Futic 35: 1116-1126.

SOARES TL, SILVA SO, COSTA MAPC, SANTOS-SEREJO JA, SOUZA AS, LINO LSM, SOUZA EH AND JESUS ON. 2008. In vitro germination and viability of pollen grains of banana diploids. Crop Breed Appl Biotec 8: 111-118.

SOARES TL, SOUZA EH, ROSSI ML AND SOUZA FVD. 2011. Morfologia e viabilidade de grãos de pólen de acessos silvestres de abacaxi. Ciênc Rural 41: 17441749.

SOARES TL, SOUZA EH, SAMPAIO LFS, COSTA MAPC, SILVA SO AND SANTOS-SEREJO JA. 2015. Effect of collection time on the viability of banana pollen grains. Afr J Biotechnol 14: 1207-1214.

SOUZA EH, SOUZA FVD, ROSSI ML, BRANCALLEÃO N, LEDO CAS AND MARTINELLI AP. 2015. Viability, storage and ultrastructure analysis of Aechmea bicolor (Bromeliaceae) pollen grains, an endemic species to the Atlantic forest. Euphytica 204: 13-28.

SOUZA FC, MENDONÇA CBF AND GONÇALVESMENDONÇA V. 2004. Estudo polínico de espécies de Pitcairnioideae e Tillandsioideae (Bromeliaceae Juss.) ocorrentes na restinga de Carapebus, Estado do Rio de Janeiro. Arq Mus Nac 62: 15-23.

STANLEY RG AND LINSKENS HF. 1974. Pollen: biology biochemistry and management. Springer-Verlag, Berlin, $310 \mathrm{p}$.

TARDIVO RC AND RODRIGUES WA. 1998. Pólen e estigma das espécies de Nidularium Leme e Cansitrum E. Morren (Bromeliaceae) ocorrentes no Estado do Paraná. Biotemas 11: 7-16.

TAYLOR LP AND HEPLER PK. 1997. Pollen germination and tube growth. Annu Rev Plant Physiol Plant Mol Biol 48: 461-491.

THOMPSON AH AND BATJER LP. 1950. The effect of boron in the germination medium on pollen germination and pollen tube growth of several deciduous tree fruits. $J$ Am Soc Hortic Sci 56: 227-230.

VERVAEKE I, PARTON E, DEROOSE R AND DE PROFT MP. 2003. Flower biology of six cultivars of the Bromeliaceae. I. pollen, pistil, and petal appendages. Selbyana 24: 78-86.

VOLK GM. 2011. Collecting pollen for genetic resources conservation. In: Guarino L et al. (Eds), Collecting plant genetic diversity: Technical guidelines - 2011 Update. chap. 25. Rome, Italy: Bioversity International, p. 1-10.

WANDERLEY MGL AND MELHEM TS. 1991. Flora polínica da Reserva do Parque Estadual das Fontes do Ipiranga - Família 178- Bromeliaceae. Hoehnea 18: 5-42.

WEE YC AND RAO AN. 1979. Ananas pollen germination. Grana 18: 3. 